\title{
PENERAPAN PENDIDIKAN KARAKTER DISIPLIN DAN TANGGUNG JAWAB SISWA DI SD NEGERI MANNURUKI KOTA MAKASSAR
}

\author{
WULAN SUCI RAMADHANI
}

17210020

Ramadhaniwulan038@gmail.com

\begin{abstract}
ABSTRAK
Karakter disiplin dan tanggung jawab merupakan salah satu nilai karakter yang ada di dalam kompetensi inti sikap sosial yang harus di kembangkan kepada peserta didik. Berdasarkan hasil observasi di SD Negeri Mannuruki Kota Makassar, sekolah ini konsisten dalam membangun budaya karakter kepada siswa, hal ini terlihat dari visi dan misi yang ingin dicapai, Kurikulum yang digunakan serta fasilitas yang disediakan.
\end{abstract}

\section{PENDAHULUAN}

Karakter merupakan sikap alami yang ada pada diri seseorang yang membedakan dengan orang lain. "Karakter ialah kualitas, kekuatan mental, moral, akhlak atau budi pekerti individu yang merupakan kepribadian khusus, yang menjadi pendorong dan penggerak, serta membedakan dengan individu lain" (Wiyani, 2013:25). Seseorang dikatakan berkarakter apabila berhasil menyerap nilai karakter yang dikehendaki masyarakat. Untuk itu, sangat penting membentuk manusia yang memiliki karakter yang baik. Pembentukan karakter dapat ditempuh melalui pendidikan karakter.

Pendidikan karakter adalah proses pemberian, penanaman, serta pembentukan karakter yang dilakukan guru untuk siswa. Pendidikan karakter menjadi pondasi utama dalam membangun karakter bangsa. Nilai-nilai karakter yang harus dikembangkan yaitu nilai karakter dalamkompetensi inti sikap spritual dan kompetensi inti sikap sosial yang terdapat di dalam Permendikbud No. 24 Tahun 2016. Diantara kedua kompetensi inti tersebut, penelitian ini hanya mengambil kompetensi inti sikap sosial. Salah satu nilai yang ada di dalam Kompetensi inti sikap sosial yaitu nilai disiplin dan tanggung jawab. Disiplin merupakan tindakan yang menunjukkan perilaku tertib dan patuh pada berbagai peraturan yang telah ditentukan, sedangkan tanggung jawab ialah sikap atau perilaku dalam melaksanakan kewajibannya.

Karakter disiplin dan tanggung jawab ditanamkan dan dibiasakan sejak dini kepada siswa, karena karakter disiplin dan tanggung jawab merupakan salah satu nilai karakter yang memegang peranan penting dalam perkembangan sikap sosial siswa. Karakter disiplin dan tanggung jawab pada siswa akan terlihat melalui perbuatan serta tindakan yang dilakukan 
dalam rutinitasnya sehari-hari di sekolah. Penerapan nilai karakter disiplin dan tanggung jawab dapat dilakukan di dalam berbagai rutinitas di lingkungan siswa. Salah satunya di lingkungan sekolah. Lingkungan sekolah sangat mempengaruhi terbentuknya karakter siswa, baik itu kegiatan yang berkaitan dengan pembelajaran maupun kegiatan di luar jam pelajaran.

Berdasarkan latar belakang masalah, terdapat suatu yang menarik untuk diteliti, karena memang kenyataannya selain nilai religius yang menjadi pondasi utama yang wajib ditanamkan. Sikap sosial disiplin dan tanggung jawab juga harus ditekankan, ditanamkan dan dibiasakan dalam rutinitas siswa di lingkungan seharihari. Untuk itu, peneliti ingin mengetahui lebih jauh penerapan pendidikan karakter disiplin dan tanggung jawab yang dilaksanakan di sekolah dengan mengadakan penelitian yang berjudul "Penerapan Pendidikan Karakter Disiplin dan Tanggung Jawab Siswa di SD Negeri Mannuruki Kota Makassar".

\section{KAJIAN TEORETIK}

Menurut Wiyani (2013:27-28) “Pendidikan karakter merupakan berbagai usaha yang dilakukan oleh para personil sekolah, bahkan yang dilakukan bersamasama dengan orang tua dan anggota masyarakat, untuk membantu anak-anak dan remaja agar memiliki sifat peduli berpendirian, dan bertanggung jawab". Sedangkan menurut Daryanto \& Darmiatun (2013:64) "pendidikan karakter merupakan usaha yang dilakukan oleh para personil sekolah, bahkan yang dilakukan bersama- sama dengan orang tua dan anggota masyarakat, untuk membantu anakanak dan remaja agar menjadi atau memiliki sifat peduli, berpendirian, dan bertanggung jawab". Kemudian menurut Gunawan (2014:24) "pendidikan karakter adalah segala sesuatu yang dilakukan guru, yang mampu mempengaruhi karakter pesertadidik".

Berdasarkan paparan teori tersebut, maka pendidikan karakter ialah proses yang dilakukan untuk mendidik siswa ke arah yang positif. Hal ini tidak hanya diberikan sekali saja, melainkan dilakukan secara terus-menerus. Pendidikan karakter menjadi hal yang diutamakan dalam pendidikan, karena pendidikan bertujuan untuk memanusiakan manusia dan menjadikan manusia memiliki kepribadian yang utuh.

Tujuan yang ingin dicapai dalam membangun karakter yaitu untuk membentuk, memperbaiki serta untuk meningkatkan karakter siswa. Menurut Mulyasa (2014:9) "pendidikan karakter bertujuan untuk meningkatkan mutu proses dan hasil pendidikan yang mengarah pada pembentukan karakter dan akhlak mulia peserta didik secara utuh, terpadu, dan seimbang, sesuai dengan Standar Kompetensi Lulusan pada setiap satuan pendidikan". Kemudian menurut Gunawan (2014:30) "Pendidikan karakter bertujuan membentuk bangsa yang tangguh, kompetitif, berakhlak mulia, bermoral, bertoleran, bergotong royong, berjiwa patriotik, berkembang dinamis, berorientasi pada ilmu pengetahuan dan teknologi yang semuanya dijiwai oleh iman dan takwa kepada Tuhan yang Maha Kuasa berdasarkan Pancasila". Dapat disimpulkan tujuan pendidikan karakter ialah untuk membentuk nilai-nilai karakter di dalam diri seseorang yang sesuai dengan ajaran agama, pancasila dan nilai- nilai yang berlaku dimasyarakat.

Menurut teori Daniel Goleman yang terkenal dengan bukunya Multiple Intelligence, dan 
emosional Intelligence (1999) (dalam buku, Adisusilo, 2014:79-80) mengungkapkan bahwa "pengembangan nilai karakter mencangkup 9 (sembilan) nilai dasar yang berkaitan, yaitu: a) Responsibility (Tanggung Jawab); b) Respect (Rasa hormat); c) Fainess (Keadilan); d) Courage (Keberanian); e) Honesty (Kejujuran); f) Citizenship (Rasa Kebangsaan); g) Self-Discipline (Disiplin Diri); h) Caring (Peduli); i) Perseverance (Ketekunan)." Dalam penelitian ini mengembangkan nilai karakter disiplin dan tanggung jawab.

Beberapa macam disiplin yang harusdikerjakan siswa antara lain: Disiplin sekolah, siswa selalu ke sekolah tepat waktu, tidak terlambat, membolos serta melarikan diri pada waktu jam pelajaran. Disiplin menyelesaikan pekerjaan, mencangkup aturan, tanggung jawab mengerjakan tugas. Disiplin pelajaran, siswa mempersiapkan peralatan belajar, mengikuti pelajaran dengan baik, menanyakan yang belum dipahami. Disiplin aturan sekolah, mengerjakan peraturan yang ditetapkan sekolah dengan penuh kesadaran.

Beberapa indikator disiplin menurut Kurinasih dan Sani (2014:68) sebagai berikut: a) Datang tepat waktu; b) Patuh pada tata tertib atau aturan bersama/sekolah; c) Mengerjakan/mengumpulkan tugas sesuai dengan waktu yang ditentukan; d) Mengikuti kaidah berbahasa tulis yang baik dan benar". Sedangkan indikator disiplin untuk di sekolah menurut Poerwati \& Amri (2013:89) sebagai berikut: "a) Memiliki catatan kehadiran; b) Memberikan penghargaan kepada warga sekolah yang disiplin; c) Memiliki tata tertib sekolah; d) Membiasakan warga sekolah untuk berdisiplin; e) Menegakkan aturan dengan memberikan sanksi secara adil bagi pelanggar tata tertib sekolah". Kemudian indikator disiplin ada yang di sekolah dan ada yang di kelas menurut Daryanto \& Darmiatun (2013:135) "Indikator disiplin di sekolah yaitu: a) memiliki catatan kehadiran; b) memberikan penghargaan kepada warga sekolah yang disiplin; c) memiliki tata tertib; d) membiasakan warga sekolah untuk berdisiplin; e) menegakkan aturan dengan memberikan sanksi secara adil bagi pelanggar tata tertib sekolah. Sedangkan indikator dalam kelas yaitu: a) membiasakan hadir tepat waktu; b) membiasakan mematuhi aturan". Jadi dalam penelitian ini peneliti menggunakan 4 indikator dari teori Kurinasih dan Sani (2014:68).

Tanggung jawab merupakan keharusan untuk dilaksanakan yang menjadi tugasnya. Menurut Yaumi (2014:114) "tanggung jawab adalah suatu kewajiban untuk melakukan atau menyelesaikan tugas (ditugaskan oleh seseorang, atau diciptakan oleh janji sendiri atau keadaan) yang seseorang harus penuhi, dan yang memiliki konsekuensi hukuman terhadap kegagalan". Menurut Daryanto dan Darmiatun (2013:142) "tanggung jawab adalah sikap dan perilaku seseorang untuk melaksanakan tugas dan kewajibannya, yang seharusnya dia lakukan, terhadap diri sendiri, masyarakat, lingkungan (alam, sosial dan budaya), negara dan Tuhan Yang Maha Esa". Menurut Suyadi (Sudibyo, dkk, 2013:103) "tanggung jawab adalah kesadaran manusia akan perbuatannya yang disengaja maupun yang tidak disengaja, serta berbuat sebagai perwujudan kesadaran akan kewajibannya". Menurut Wiyani (2013:49) "tanggung jawab ialah bentuk karakter seseorang yang membuat dirinya bertanggung jawab, disiplin, dan selalu melakukan sesuatu dengan sebaik mungkin". Kemudian menurut Nashir (2013:82) mengemukakan bahwa "tanggung jawab ialah kesadaran pada diri sendiri untuk melaksanakan tugas atau kewajiban". Jadi tanggung jawab ialah perilaku atau sikap seseorang dalam melaksanakan sesuatu yang menjadi kewajibannya. Khususnya siswa, karena siswa mempunyai tanggung jawab belajar 
Macam-macam tanggung jawab menurut Sudibyo, dkk (2013:106) diantaranya: "a) Tanggung jawab terhadap diri sendiri, menuntut untuk memenuhi kewajibannya sendiri; $b$ ) Tanggung jawab terhadap manusia atau masyarakat, menuntut adanya kesadaran manusia memenuhi kewajibannya dalam hubungan hidup bermasyarakat; c) Tanggung jawab terhadap lingkungan, menuntut kesadaran manusia untuk melaksanakan kewajibannya atau pengorbananya dalam lingkungan hidup yang baik, teratur, sehat; d) Tanggung jawab terhadap Tuhan, menuntut kesadaran mau memenuhi pengabdian terhadap Tuhan Yang Maha Kuasa"

Beberapa indikator tanggung jawab, menurut Daryanto \& Darmiatun (2013:142) adapun indikator dari tanggung jawab "'Indikator di sekolah dan di kelas, sebagai berikut: Indikator tanggung jawab di sekolah, yaitu: a) Membuat laporan setiap pekerjaan yang dilakukan dalam bentuk lisan maupun tertulis; b) Melakukan tugas tanpa disuruh; c) Menunjukkan prakarsa untuk mengetahui masalah dalam lingkup terdekat; d) Menghindarkan kecurangan dalam pelaksanaan tugas. Sedangkan indikator tanggung jawab di kelas yaitu: a) Pelaksanaan tugas piket secara teratur; b) Peran serta aktif dalam kegiatan sekolah; c) Mengajukan usul pemecahan masalah". Menurut Kurinasih dan Sani (2014:69) indikator tanggung jawab "I) Melaksanakan tugas individu dengan baik; 2) Menerima resiko dan tindakan yang dilakukan; 2) Tidak menyalahkan/menuduh orang lain tanpa bukti yang akurat; 3 ) Mengembalikan barang yang dipinjam; 4) Mengakui dan meminta maaf atas kesalahan yang dilakukan; 4) Menepati janji; 5) Tidak menyalahkan orang lain untuk kesalahan tindakan sendiri; 6) Melaksanakan apa yang pernah dikatakan tanpa disuruh/diminta". Jadi indikator yang digunakan peneliti diantaranya 1) Melaksanakan tugas individu dengan baik; 2) Menerima resiko dari perbuatan/tindakan yang dilakukan; 3) Pelaksanaan tugas piket secara teratur; 4) Peran serta aktif dalam kegiatan sekolah.

Berdasarkan bahan pelatihan tentang pengembangan budaya dan karakter bangsa yang dikeluarkan oleh Kemendiknas (2010: 14-21) menyebutkan bahwa pengembangan nilai-nilai karakter dapat dilakukan dengan program pengembangan diri yang meliputi kegiatan rutin sekolah, kegiatan spontan, keteladanan dan pengkondisian.Pengintegrasian dalam mata pelajaran yang meliputi silabus, RPP, dan kegiatan pembelajaran. Pengintegrasian dalam budaya sekolah yang meliputi buday kelas, sekolah, dan luar sekolah.

\section{METODE PENELITIAN}

Berdasarkan tujuan penelitian, maka jenis penelitian ini deskriptif kuantitatif dengan metode penelitian survei. Adapun tujuan dalam penelitian ini yaitu untuk mengetahui dan mendeskripsikan penerapan pendidikan karakter disiplin dan tanggung jawab siswa di SD Negeri Mannuruki Kota Makassar serta untuk mengetahui perilaku siswa SD Negeri Mannuruki Kota Makassar dalam menerapkan karakter disiplin dan tanggung jawab. Jadi, jenis deskriptif kuantitatif merupakan upaya untuk menggambarkan suatu hal yang terjadi di lapangan berdasarkan keadaan yang sebenarnya dengan menggunakan angkat, tanpa menguji suatu hipotesis.

Populasi ialah keseluruhan yang terdiri dari subjek maupun objek yang mempunyai karakteristik tertentu yang ditetapkan peneliti. Populasi dalam penelitian ini adalah seluruh siswa di SD Negeri Mannuruki Kota Makassar yang berjumlah 630 siswa. Setelah diidentifikasi 
keseluruhan populasi mempunyai 2 karakteristik, pertama karakteristik dari teknik sampel stratified (tingkatan/berstrata); kedua mempunyai karakteristik dari teknik cluster (perbedaan). Sampel digunakan untuk memperkecil atau mempersempit populasi. Sampel diambil sebanyak $20 \%$ dari keseluruhan populasi, maka diperoleh sampel sebanyak 120 siswa. Teknik pengambilan sampel berdasarkan karakteristik populasi yaitu dengan teknik proportionate stratified cluster random sampling, teknik ini digunakan karena di dalam populasi mempunyai anggota/unsur yang tidak homegen dan berstrata secara proporsional.

Teknik pengumpulan data diartikan berbagai cara atau prosedur yang dilakukan dalam mengumpulkan data. Adapun teknik pengumpulan data yang digunakan dalam penelitian ini yaitu teknik wawancara (wawancara tidak terstruktur), teknik angket (Questionnaire) dan teknik observasi (observasi non partisipan).

Instrumen penelitian ialah alat atau fasilitas yang digunakan peneliti dalam mengumpulkan data agar pekerjaan lebih mudah dan hasilnya lebih baik. Adapun instrumen yang digunakan dalam penelitian ini berupa instrumen wawancara (wawancara tidak terstruktur), lembar angket instrumennya sebelumnya di uji dengan mengunakan validitas konstruk. Berikut di bawah ini adalah pernyataan dari angket.

Tabel. 3.2 Kisi-Kisi Instrumen Angket

\begin{tabular}{|c|c|c|c|}
\hline $\begin{array}{c}\text { Nilai } \\
\text { Karakter }\end{array}$ & Indikator & Deskriptor & $\begin{array}{c}\text { Nomor } \\
\text { Item }\end{array}$ \\
\hline \multirow{8}{*}{ Disiplin } & \multirow[t]{2}{*}{ Datang tepat waktu } & $\begin{array}{l}\text { Saya datang ke sekolah sesuai dengan waktu } \\
\text { yang dijadwalkan }\end{array}$ & 1 \\
\hline & & $\begin{array}{l}\text { Saya pulang sekolah tepat waktu yang } \\
\text { dijadwalkan sekolah }\end{array}$ & 2 \\
\hline & \multirow{2}{*}{$\begin{array}{l}\begin{array}{l}\text { Patuh pada tata tertib } \\
\text { atau } \\
\text { bersama/sekolah }\end{array} \\
\text { aturan }\end{array}$} & $\begin{array}{l}\text { Saya menaati tata tertib dalam kelas maupun } \\
\text { di luar kelas }\end{array}$ & 3 \\
\hline & & $\begin{array}{l}\text { Saya melaksanakan setiap aturan yang } \\
\text { dibuat sekolah }\end{array}$ & 4 \\
\hline & \multirow{3}{*}{$\begin{array}{l}\text { Mengerjakan/mengumpu } \\
\text { lkan tugas sesuai dengan } \\
\text { waktu yang ditentukan }\end{array}$} & $\begin{array}{l}\text { Saya selalu mengerjakan tugas yang } \\
\text { diberikan }\end{array}$ & 5 \\
\hline & & Saya menyelesaikan tugas tepat waktu & 6 \\
\hline & & $\begin{array}{l}\text { Saya mengumpulkan tugas sesuai waktu } \\
\text { yang di tentukan }\end{array}$ & 7 \\
\hline & $\begin{array}{l}\text { Mengikuti kaidah } \\
\text { berbahasa tulis yang baik } \\
\text { dan benar }\end{array}$ & $\begin{array}{l}\text { Saya berbahasa sopan terhadap teman } \\
\text { maupun guru }\end{array}$ & 8 \\
\hline Tanggung & Melaksanakan & Saya mengerjakan tugas sendiri dengan baik & 9 \\
\hline
\end{tabular}

\begin{tabular}{|c|c|c|c|}
\hline \multirow[t]{5}{*}{ Jawab } & \multirow[t]{2}{*}{ idivindu dengan baik } & tanpa adanya bantuan dari orang lain & \\
\hline & & $\begin{array}{l}\text { Saya mengerjakan tugas sesuai dengan } \\
\text { arahan dan ketentuan yang diperintahkan }\end{array}$ & 10 \\
\hline & $\begin{array}{l}\text { Menerima resiko dari } \\
\text { perbuatan/tindakan yang } \\
\text { dilakukan }\end{array}$ & $\begin{array}{l}\text { Saya menerima sanksi/hukuman apabila } \\
\text { melanggar aturan/tata tertib baik di kelas } \\
\text { maupun di luar kelas }\end{array}$ & 11 \\
\hline & \multirow{2}{*}{ 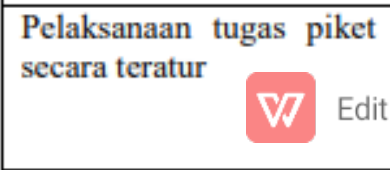 } & $\begin{array}{l}\text { Saya melaksanakan tugas piket yang telah } \\
\text { dijadwalkan }\end{array}$ & 12 \\
\hline & & $\begin{array}{l}\text { dSagariktiP Snetaksanakan tugas piket sesuai } \\
\text { dengan pembagian tugas yang diberikan }\end{array}$ & 13 \\
\hline
\end{tabular}




\section{HASIL PENELITIAN DAN PEMBAHASAN}

Hasil penelitian

SD Negeri Mannuruki Kota Makassar merupakan salah satu sekolah yang konsisten dalam membangun budaya karakter. Hal tersebut terlihat jelas dari visi dan misi sekolah, Kurikulum 2013 yang digunakan lebih menekankan aspek sikap kepada siswa, serta fasilitas yang disediakan sekolah. Meskipun penanaman dan mengembangkan nilai-nilai karakter di sekolah tersebut nampak konsisten dan fasilitas yang disediakan cukup mendukung dalam penerapannya, namun penerapan pendidikan karakter disiplin dan tanggung jawab di sekolah tersebut terlihat tidak dikhususkan pada kegiatan maupun pada mata pelajaran tertentu, melainkan hanya diterapkan di sela-sela kegiatan, baik kegiatan di lingkungan sekolah maupun di dalam kegiatan pembelajaran.

Berdasarkan hasil wawancara dan observasi yang telah dilakukan, dapat disimpulkan bahwa penerapan pendidikan karakter disiplin dan tanggung jawab di sekolah tersebut sangat berperan penting. Hal ini berdasarkan Kurikulum yang digunakan, visi dan misi yang diterapkan serta pendapat dari kepala sekolah dan guru mengenai pentingnya penanaman karakter disiplin dan tanggung jawab sejak dini kepada siswa. Hasil penerapan nilai karakter disiplin dan tanggung jawab di sekolah tersebut dapat di lihat di bawah ini.

Tabel 4.1 Hasil Observasi Penerapan Pendidikan Karakter Disiplin dan Tanggung Jawab di SD Negeri Mannuruki Kota Makassar.

\begin{tabular}{|c|c|c|c|c|c|}
\hline \multirow{2}{*}{ Indikator } & \multirow{2}{*}{ Sub Indikator } & \multicolumn{4}{|c|}{ Kriteria Jawaban } \\
\hline & & 1 & 2 & 3 & 4 \\
\hline \multirow{4}{*}{$\begin{array}{l}\text { Program } \\
\text { Pengembangan } \\
\text { Diri }\end{array}$} & Kegiatan Rutin & & & $\sqrt{ }$ & \\
\hline & Kegiatan Spontan & & & & $\sqrt{ }$ \\
\hline & Keteladanan & & & & $\sqrt{ }$ \\
\hline & Pengkondisian & & & & $\sqrt{ }$ \\
\hline \multirow{3}{*}{ Mata Pelajaran } & Silabus & & & & $\sqrt{ }$ \\
\hline & RPP & & & & $\sqrt{ }$ \\
\hline & Kegiatan Pembelajaran & & & & $\sqrt{ }$ \\
\hline \multirow{3}{*}{ Budaya Sekolah } & Kelas & & & $\sqrt{ }$ & \\
\hline & Sekolah & & & $\sqrt{ }$ & \\
\hline & Luar Sekolah & & $\sqrt{ }$ & & \\
\hline \multicolumn{2}{|c|}{$\sum$ Skor yang muncul } & \multicolumn{4}{|c|}{35} \\
\hline \multicolumn{2}{|c|}{ Persentase yang diperoleh } & \multicolumn{4}{|c|}{$87.5 \%$} \\
\hline \multicolumn{2}{|l|}{ Predikat } & \multicolumn{4}{|c|}{ BAIK } \\
\hline
\end{tabular}


Berdasarkan jumlah skor kriteria yang diperoleh dari 10 sub indikator tersebut, persentase yang didapatkan dengan menggunakan rumus persentase yang diperoleh $=\mathrm{x} 100 \%$ $=\mathrm{x} 100 \%=$. Berdasarkan hasil penerapan di atas, maka penerapan pendidikan karakter disiplin dan tanggung jawab di SD Negeri Mannuruki Kota Makassar yang diintegrasikan dalam program pengembangan diri yang meliputi kegiatan rutin, kegiatan spontan, keteladanan, dan pengkondisian. Selanjutnya diintegrasikan dalam mata pelajaran yang dicantumkan di dalam silabus, RPP, dan di dalam kegiatan pembelajaran. Kemudian diintegrasikan dalam budaya sekolah yang meliputi budaya kelas, sekolah, dan di luar sekolah. Kegiatan rutin memperoleh skor 3, kegiatan rutin yang dilakukan di SD Negeri Mannuruki Kota Makassar meliputi kegiatan rutin harian, rutin mingguan dan rutin Bulanan. Kegiatan rutin harian seperti menunggu siswa di depan pintu gerbang sekolah, mengajak siswa membuang sampah yang berserakan di lapangan sekolah, memeriksa kebersihkan kelas, dan mengadakan literasi. Kegiatan rutin mingguan meliputi kegiatan ekstrakurikuler pramuka, olahraga, senam pagi setiap hari Sabtu dan yasinan setiap hari Jumat. Kegiatan rutin bulanan meliputi kegiatan jalan santai.

Kegiatan spontan memperoleh skor 4. Kegiatan spontan dilakukan guru tanpa direncanakan terlebih dahulu, kegiatan ini dilakukan begitu saja. Kegiatan ini dilakukan apabila nampak siswa melakukan perbuatan yang tidak sesuai dengan ketentuan, serta bisa juga memuji siswa apabila siswa melakukan perbuatan yang sesuai dengan aturan atau perbuatan baik. Kegiatan spontan terjadi baik di dalam kelas maupun di luar kelas. Kegiatan spontan di kelas seperti guru menegur dan menasehati siswa jika ada siswa yang kedapatan mencontek, kegiatan spontan dilakukan juga ketika siswa dapat mempertanggung jawabkan hasil pekerjaanya di depan kelas dengan cara memuji siswa tersebut. Kegiatan spontan di luar kelas seperti menegur siswa apabila kedapatan membuang sampah sembarangan, terlambat datang ke sekolah, tidak mengikuti upacara bendera. Selain itu, megumpulkan dana apabila ada warga sekolah yang terkena musibah.

Keteladanan memperoleh skor 4. Keteladanan dilakukan oleh guru agar dapat dijadikan contoh bagi siswa untuk berbuat baik. Bentuk keteladan yang terkait dengan penerapan pendidikan karakter disiplin dan tanggung jawab di SD Negeri Mannuruki Kota Makassar, yaitu keikutsertaan guru dalam kegiatan-kegiatan yang diadakan sekolah.

Selanjutnya diintegrasikan dalam budaya sekolah meliputi budaya di kelas, sekolah dan luar sekolah. Budaya kelas memperoleh skor 3. Budaya kelas yang mencerminkan karakter disiplin dan tanggung jawa sama halnya dengan kegiatan rutin yang dilakukan sekolah setiap hari, seperti berdoa sebelum dan sesudah pembelajaran, membersihkan kelas sebelum kegiatan pembelajaran di mulai, dan mengadakan literasi. Sedangkan budaya sekolah memperoleh skor 3. Budaya sekolah yang mencerminkan karakter disiplin dan tanggung seperti sebagian guru selalu datang lebih awal, kemudian menunggu siswa di depan pintu gerbang sekolah memastikan siswa tidak ada yang terlambat, siswa menyalami ketika bertemu guru serta selalu mengikuti kegiatan- kegaiatan yang diadakan sekolah. Kemudian budaya di luar sekolah memperoleh skor 2. Budaya di luar sekolah yang mencerminkan karakter disiplin dan 
tanggung jawab yaitu salah satunya mengikuti lomba-lomba yang diadakan antar sekolah maupun dari pihak lain, yang terdiri dari berbagai macam jenis lomba seperti perkemahan pramuka antar sekolah, cerdas cermat, drumband, dan lain-lain. Di sini anak diajarkan untuk bersikap sesuai dengan aturan dari kegiatan yang diadakan dan bertanggung jawab penuh dengan kegiatan yang diikuti.

Faktor lain pendukung atau penunjang penerapan pendidikan karakter disiplin dan tanggung jawab di SD Negeri Mannuruki Kota Makassar yaitu dilihat dari fasilitas yang disediakan sekolah, seperti: alat-alat kebersihan, tempat mencuci tangan dan slogan-slogan yang disediakan sekolah. Kemudian kendalan dalam penerapan pendidikan karakter disiplin dan tanggung jawab di sekolah tersebut yaitu membutuhkan waktu lama untuk menerapkan karakter disiplin dan tanggung jawab kepada siswa.

Hasil analisis data nilai karakter disiplin dan tanggung jawab diolah dengan menggunakan bantuan SPSS. Hasil uji deksriptif perilaku siswa dalam menerapkan nilai karakter meliputi jumlah data yang valid, rata-rata (mean), nilai tengah (median), nilai yang sering muncul (modus), nilai maksimum dan nilai minimum. Hasil datanya dianalisis, dideskripsikan kemudian ditarik kesimpulannya mengenai perilaku siswa dalam menerapkan karakter tersebut. Perilaku siswa SD Negeri Mannuruki Kota Makassar dalam menerapkan karakter disiplin pada kategori cukup dengan persentase $58.3 \%$, sebanyak 70 siswa. Hasil analisis data perbutir pernyataan karakter disiplin persentase tertinggi pada butir ke 2, sedangkan persentase terendah pada butir ke 7. Sedangkan perilaku siswa SD Negeri Mannuruki Kota Makassar dalam menerapkan karakter tanggung jawab pada kategori cukup $57.5 \%$, sebanyak 69 siswa. Hasil analisis data perbutir pernyataan karakter tanggung jawab persentase tertinggi pada butir ke 4, dan persentase terendah pada butir ke 6 .

\section{Pembahasan}

Penerapan pendidikan karakter sangatlah penting untuk ditanamkan kepada siswa sejak dini, karena semakin dini pendidikan karakter ditanamkan dan dibiasakan maka semakin baik pula karakter yang dihasilkan. Sependapat menurut Wiyani (2013:27-28) "pendidikan karakter adalah proses pemberian tuntunan kepada peserta didik untuk menjadi manusia seutuhnya, yang berkarakter dalam dimensi hati, pikir, raga, serta rasa dan karsa". Tujuan dari adanya pendidikan karakter yaitu untuk menghasilkan manusia yang berkarakter. Senada dengan Mulyasa (2014:9) "pendidikan karakter bertujuan untuk meningkatkan mutu proses dan hasil pendidikan yang mengarah pada pembentukan karakter dan akhlak mulia peserta didik secara utuh, terpadu, dan seimbang, sesuai dengan Standar Kompetensi Lulusan pada setiap satuan pendidikan".

Penerapan pendidikan karakter disiplin dan tanggung jawab siswa di SD Negeri Mannuruki Kota Makassar, terkait dengan indikator dari penerapan pendidikan yang diintegrasikan melalui program pengembangan diri yang meliputi kegiatan rutin, kegiatan spontan, keteladanan, dan pengkondisian. Selanjutnya diintegrasikan di dalam mata pelajaran yang meliputi Silabus, RPP, dan kegiatan pembelajaran. Kemudian diintegrasikan melalui budaya di sekolah yang meliputi budaya kelas, sekolah, dan luar sekolah. Hasil yang didapatkan 
berdasarkan indikator tersebut yaitu persentase (87.5\%), dengan predikat baik.

Pengintegrasian dalam program pengembangan diri meliputi kegiatan rutin, kegiatan rutin sekolahyang diterapkan di SD Negeri No. 13/1 Muara Bulian, meliputi kegiatan rutin harian, mingguan, dan kegiatan rutin bulanan. Sependapat menutu Wiyani (2013:104) "kegiatan rutin adalah kegiatan yang dikerjakan anak didik secara terus menerus dan konsisten dari waktu ke waktu". Kegiatan spontan dilakukan guru tanpa direncanakan sebelumnya, kegiatan ini biasanya dilakukan apabila melihat anal yang berbuat tidak sewajarnya, bisa juga memuji anak ketika melakukan perbuatan yang baik. Sejalan dengan pendapat Wiyani (2013:104) "kegiatan spontan merupakan kegiatan yang dilaksanakan pada waktu itu juga". Keteladanan yang dilakukan guru menjadi contoh bagi siswanya untuk berbuat baik. Hal ini didukung dengan pendapat Wiyani (2013:105) "keteladanan adalah sikap dan perilaku guru, tenaga kependidikan, dan anak didik dalam menunjukkan contoh dalam hal berperilaku dan bertindak secara baik dan benar". Untuk menanamkan dan menerapkan karakter disiplin dan tanggung jawab, sekolah mengkondisikan segala sesuatu yang berhubungan dengan penerapan pendidikan karakter disiplin dan tanggung jawab. Senada dengan pendapat Wiyani (2013:104) "pengondisian yaitu membuat keadaan dan suasana yang akan menunjang terlaksananya pendidikan karakter untuk mendukung terwujudnya internalisasi nilai karakter ke dalam diri siswa".

Penerapan pendidikan karakter disiplin dan tanggung jawab diintegrasikan dalam mata pelajaran dengan ketentuan sesuai dengan materi dan tujuan yang akan dicapai. Pengintegrasian dalam mata pelajaran yaitu dengan menyisipkannya dalam pelajaran ketika menyampaikan materi kepada siswa apabila materi tersebut berhubungan dengan karakter disiplin dan tanggung jawab.

Budaya sekolah yang meliputi budaya kelas, budaya kelas yaitu budaya yang berkenaan dengan penerapan pendidikan karakter disiplin dan tanggung jawab yang terlihat dari kegiatankegiatan yangbiasa dilakukan di dalam kelas dan sudah menjadi kebiasaan siswa melakukan hal tersebut. Seperti yang diungkapkan Kemendiknas (2010:20) "pelaksanaan nilai-nilai karakter melalui pengintegrasian budaya sekolah di kelas meliputi proses belajar setiap mata pelajaran atau kegiatan yang dirancang sedemikian rupa. Budaya sekolah merupakan kebiasaankebiasaan yang sering dilakukan oleh seluruh warga di sekolah tersebut. Senada dengan yang diungkapkan oleh Kemendiknas (2010:21) penerapan nilai-nilai karakter dilaksanakan melalui pengintegrasian budaya sekolah yaitu melalui berbagai kegiatan yang diadakan sekolah yang diikuti seluruh warga sekolah, diantaranya siswa, guru, kepala sekolah, serta tenaga administrasi di sekolah itu, direncanakan sejak awal tahun pelajaran, dimasukkan ke Kalender Akademik dan yang dilakukan sehari-hari sebagai bagian dari budaya sekolah. Kemudian budaya di luar sekolah merupakan kebiasaan atau bentuk kegiatan yang sering dilakukan di luar sekolah. Senada dengan yang disampaikan oleh Kemendiknas (2010:22) "pengintegrasian nilainilai karakter di luar sekolah dilakukan melalui kegiatan ekstrakurikuler dan kegiatan lain yang diikuti oleh seluruh atau sebagian peserta didik, dirancang sekolah sejak awal tahun pelajaran, dan dimasukkan ke dalam Kalender Akademik". Bentuk kegiatan yang mencerminkan penerapan nilai karakter disiplin dan tanggung jawab, seperti ikut serta dalam kegiatan ekstrakurikuler pramuka, olah raga, dan lain-lain serta mengikuti lomba-lomba yang diadakan antar sekolah. 
Hasil analisis angket perilaku siswa dalam menerapkan karakter disiplin, pada kategori cukup dengan persentase (58.3\%). Hasil yang diperoleh menjadi bahan evaluasi bagi sekolah untuk lebih meningkatkan dan menekankan penerapan pendidikan karakter disiplin kepada siswa, karena karakter disiplin merupakan tindakan siswa yang menunjukkan perilaku tertib dan patuh dalam melaksanakan berbagai aturan yang diterapkan sekolah. Senada dengan pendapat Kurinasih dan Sani (2014:69) "disiplin merupakan tindakan yang menunjukkan perilaku tertib dan patuh pada berbagai ketentuan dan peraturan". Hasil perbutir dari 8 pernyataan karakter disiplin, untuk persentase tertinggi pada butir ke 2, dengan persentase 84.1\%, sebanyak 101 siswa yang menyatakan selalu pulang sekolah tepat waktu yang dijadwalkan sekolah. Sedangkan persentase terendah dari 8 butir penyataan karakter disiplin berada pada butir ke 7 dengan persentase sebesar $39.2 \%$, sebanyak 47 siswa yang menyatakan selalu mengumpulkan tugas sesuai waktu yang ditentukan, hasil yang didapatkan merupakan gambaran perilaku siswa terhadap karakter disiplin, Upaya yang sebaiknya dilakukan sekolah untuk mengatasi hal tersebut yaitu dengan cara: 1) sebaiknya guru secara terus-menerus menerapkan nilai karakter disiplin dalam diri siswa, sehingga nilai tersebut menjadi membudaya dalam dirinya; dan 2) memanggil orang tua siswa, untuk menjalin komunikasi mengenai sikap siswa tersebut.

Hasil angket perilaku siswa dalam menerapkan karakter tanggung jawab, pada kategori baik cukup dengan persentase (57.5\%). Hasil yang diperoleh menjadi bahan evaluasi bagi sekolah untuk lebih menekankan penerapan pendidikan karakter tanggung jawab kepada siswa, karena karakter tanggung jawab merupakan kewajiban siswa dalam melaksanakan berbagai aturan maupun tugas yang dibebankan kepadanya. Senada dengan yang sampaikan Daryanto \& Darmiatun (2013:142) "tanggung jawab adalah sikap dan perilaku seseorang untuk melaksanakan tugas dan kewajibannya, yang seharusnya dia lakukan, terhadap diri sendiri, masyarakat, lingkungan (alam, sosial dan budaya), negara dan Tuhan Yang Maha Esa”. Hasil perbutir dari 6 pernyataan karakter tanggung jawab, untuk persentase tertinggi pada butir ke 4, dengan persentase $53.3 \%$, sebanyak 64 siswa yang menyatakan selalu melaksanakan tugas piket sesuai dengan pembagian tugas yang diberikan. Sedangkan persentase terendah dari 6 butir penyataan karakter tanggung jawab berada pada butir 6 dengan persentase sebesar $41.7 \%$, sebanyak 50 siswa yang menyatakan selalu ikut dalam kegiatan sekolah, hasil yang didapatkan merupakan gambaran perilaku siswa terhadap karakter tanggung jawab, upaya yang sebaiknya dilakukan sekolah untuk mengatasi hal tersebut yaitu dengan cara memanggil orang tua siswa, untuk menjalin komunikasi mengenai sikap siswa tersebut.

\section{SIMPULAN, IMPLIKASI, DAN SARAN}

\section{Simpulan}

Berdasarkan hasil penelitian dan pembahasan, dapat peneliti simpulkan bahwa SD Negeri No. 13/1 Muara Bulian merupakan sekolah yang konsisten dalam membangun karakter. Hal ini nampak dari rumusan visi dan misi, Kurikulum yang digunakan, serta fasilitas yang disediakan.

Hasil dari penerapan pendidikan karakter disiplin dan tanggung jawab siswa di SD Negeri No.13/1 Muara Bulian terlaksana dengan baik dengan persentase (87.5\%). Hasil yang 
didapatkan terkait indikator penerapan pendidikan karakter disiplin dan tanggung jawab. Pertama diintegrasikan dalam program pengembangan diri yang meliputi kegiatan rutin, kegiatan spontan, keteladanan, dan pengkondisian. Kegiatan rutin yang diterapkan sekolah meliputi kegiatan rutin harian, mingguan dan bulanan. Kegiatan spontan dilakukan saat itu juga tanpa direncanakan sebelumnya. Keteladanan biasanya dilakukan guru untuk dapat menjadi contoh yang baik. Kemudian pengkondisian seperti menyediakan kondisi sekolah yang baik untuk menunjang penerapan pendidikan karakter. Kedua diintegrasikan di dalam mata pelajaran yang meliputi Silabus, RPP, dan kegiatan pembelajaran, penerapannya dilakukan dengan mencantumkan nilai-nilai karakter di dalamnya. Ketiga diintegrasikan di dalam budaya sekolah meliputi budaya di kelas, sekolah, dan luar sekolah. Budaya tersebut merupakan kegiatan yang sering dilakukan yang sudah menjadi kebiasaan siswa baik di dalam kelas, di sekolah, maupun di luar sekolah. Sedangkan perilaku siswa SD Negeri No. 13/1 Muara Bulian dalam menerapkan karakter disiplin pada kategori cukup dengan persentase (58.3\%), sebanyak 70 siswa. Selanjutnya perilaku siswa dalam menerapkan tanggung jawab pada kategori cukup dengan persentase (57.5\%), sebanyak 69 siswa.

Implikasi

Hasil penelitian ini berupa hasil dari penerapan pendidikan karakter disiplin dan tanggung jawab siswa di SD Negeri No. 13/1 Muara Bulian, serta hasil dari perilaku siswa SD Negeri No. 13/1 Muara Bulian dalam menerapkan karakter disiplin dan tanggung jawab. Penerapan pendidikan karakter disiplin dan tanggung jawab sudah menjadi kegiatan rutin yang sudah membudaya di sekolah, kegiatan ini akan berdampak baik untuk perserta didik, karena semakin dini seorang anak menerima pendidikan karakter disiplin dan tanggung jawab, maka semakin baik pula karakter yang akan dihasilkan.

Saran

Berdasarkan simpulan, maka dalam kesempatan ini peneliti ingin menyampaikan saran sebagai berikut:

1. Sekolah hendaknya lebih menekankan penerapan nilai karakter disiplin dan tanggung jawab, sehingga perilaku tersebut lebih baik dari sebelumnya.

2. Untuk mengatasi kekurangan dari aspek nilai karakter tersebut, sebaiknya sekolah ada langkah-langkah tertentu untuk mengatasi kekurangan tersebut.

3. Untuk penelitian selanjutnya, hendaknya tidak hanya melihat karakter disiplin dan tanggung jawab saja, sebaiknya semua yang ada di dalam kompetensi inti sikap sosial, serta sebaiknya penelitian yang akan ada tindakan yang diberikan

DAFTAR RUJUKAN 
Adisusilo, S. (2014). Pembelajaran Nilai-Karakter: Konstruktivisme dan VCT sebagai Inovasi Pendekatan Pembelajaran Afektif. Jakarta: PT Raja Grafindo Persada

Amazona, R. H. (2016). Implementasi Pendidikan Karkter di Sekolah Dasar Islam Terpadu Hidayatullah Yogyakarta. Skripsi. Yogyakarta: Universitas Negeri Yogyakarta

Ary, D., Jacobs, L.C \& Rozavieh, A. (2011). Pengantar Penelitian Pendidikan. Terjemahan oleh Arif Furchan. Yogyakarta: Pustaka Pelajar Offset

Daryanto \& Darmiatun, S. (2013). Implementasi Pendidikan Karakter di Sekolah. Yogyakarta: Gava Media

Daryanto \& Darmiatun, S. (2013). Implementasi Pendidikan Karakter di Sekolah. Yogyakarta: Gava Media

Arsyam m. (2020) pengaruh kemampuan supervisional kepala sekolah dan peran komite sekolah terhadap kinerja guru sma negri di kota makassar.

Arsyam m. dan umar, k, (2020)manusia sebagai pendidik perspektif islam dan barat.

Arsyam m. jumliadi, m. H, dan alwi, a. M. S. (2020) pembelajaran dirumah dalam lingkungan keluarga di tengah pandemi covid 19.

Herianto, h, \& hamid, n (2020) Analisis proses berpikir kreatif dalam pemecahan masalah geometri berdasarkan gaya kognitif reflektif dan influsif siswa. Pedagogy : jurnal pendidikan matematika 5. (2), 38-49

Herianto h, (2020) teknik menulis artikel konseptual.

Herianto h, (2019) PENERAPAN METODE ACCELERATED LEARNING FOR 21 st CENTURY DALAM MENINGKATKAN HASIL BELAJAR MATEMATIKA SISWA. Delta : jurnal ilmiah pendidikan matematika, 7(2), 37(50).

Jusmiana, A., herianto, H..,\& awalia, R. (2020). Pengaruh penggunaan media Audio visual Terhadap Hasil Belajar Matematika Siswa Smp Di Era Pandemi Covid-19 pedagogy jurnal pendidikan matematika, 5(2), 1-11. 